\title{
RUSSIAN CHRONICLES ON THE RELIGIOUS POLICY OF UZBEK KHAN (1313-1341) AND HIS RELATIONS WITH THE PRINCIPALITIES OF THE NORTH-EASTERN RUS'
}

\author{
Roman Hautala ${ }^{1,2}$ \\ ${ }^{1}$ Sh.Marjani Institute of History of Tatarstan Academy of Sciences \\ Kazan, Russian Federation \\ ${ }^{2}$ University of Oulu \\ Oulu, Finland \\ romanhautala@gmail.com
}

Research objectives: The author of present article examines the overall response of Russian medieval scribes to the ascension to power of Uzbek Khan - the Golden Horde's Muslim ruler who made a major effort to spread Islam in the Jochid Empire. Analyzing Russian sources, the author tries to answer the question regarding to what extent we can trust the reliability of their information about the impact of Uzbek's religious affiliation on the anticipated change in his relations with the Russian principalities.

Research materials: Russian sources are of paramount importance for the study of the Golden Horde's history. On the one hand, Russian chronicles contain a wealth of relevant factual material. The abundance of this material can be explained by the fact that medieval Rus' was subordinated to the Golden Horde, although its numerous and disjointed princes enjoyed considerable autonomy within the Jochid Empire. On the other hand, the accuracy of Russian chronicles' information should not be overestimated for several reasons. The preserved chronicle collections were often composed several centuries after the described events. Therefore, their information underwent the influence of significant ideological changes. In addition, the authors of Russian chronicles focused on the description of only those events that were directly related to the Russian principalities and their rulers.

The novelty of this study emerges from a comparison of the Russian chronicles' content with information found in little-known written sources. In particular, Latin sources compiled within the ulus of Jochi in a relatively large amount exactly during the period under study compensate to some extent for the complete absence of Jochid written sources. In this case, the content of the Latin sources will allow us to reconsider the established opinion about the total Islamization of the ulus of Jochi during Uzbek's reign.

Research results: The use of heterogeneous written sources underlies the significance of the present study. Comparison of the Russian chronicles' content with information of Catholic missionaries, who preached the Gospel in the Golden Horde, allows the author to demonstrate that the Muslim ruler, Uzbek, adhered to the traditional Chinggisid principles of religious tolerance throughout his entire reign.

Keywords: Golden Horde, North-Eastern Rus', reign of Uzbek Khan, Islamization of the Tartars, Russian chronicles, Latin sources

For citation: Hautala R. Russian Chronicles on the Religious Policy of Uzbek Khan (1313-1341) and His Relations with the Principalities of the North-Eastern Rus'. Zolotoordynskoe obozrenie $=$ Golden Horde Review. 2017. Vol. 5, no. 4, pp. 736-755. DOI: 10.22378/2313-6197.2017-5-4.736-755 
Uzbek Khan's reign in the Golden Horde is particularly interesting for two main reasons. Firstly, Uzbek's period is abundantly described by heterogeneous Oriental, Russian and Latin sources. In particular, Latin sources compiled within the ulus of Jochi in a relatively large amount exactly during this period to some extent compensate the complete absence of Jochid own written sources. Secondly, Uzbek's reign is interesting because he was a Muslim and made a major effort to spread Islam in the Golden Horde.

Uzbek Khan's religious affiliation was to have direct relevance to Rus' since, as we know, its population professed Orthodoxy: North-Eastern Rus' was subordinated to the Golden Horde, although its numerous and disjointed princes enjoyed considerable autonomy within the Jochid Empire. Therefore, a change of religion of supreme ruler of Rus' should have been reflected in Russian written sources and we will pay here our main attention to the consideration of this reflection.

However, anticipating the content analysis of Russian sources, we will pay special attention first of all to both the analysis of the religious situation within the Golden Horde and the confessional changes among nomads that occurred as a result of Uzbek's ascension to power. Information of both Muslim and Catholic written sources will provide us an invaluable service in the process of analysis. In this case, the content of the Latin sources will allow us to reconsider the established opinion about the total Islamization of the ulus of Jochi during Uzbek's reign.

Next, we will consider the overall response of Russian medieval authors to Uzbek Khan's ascension to power and, in particular, the degree of hostility towards religious orientation of the new Golden Horde ruler. We will also pay special attention here to legal acts drawn up by the Office of the khan that most directly reflect Uzbek's attitude to the Christian clergy within his domain.

After that, we will pay attention to two narratives, which enjoyed an increased popularity among Russian medieval scribes and were included in most of the Russian chronicles. We are referring to the "Tale of Michael of Tver" and "Scholkanovschina", which clearly reflect a negative attitude towards new religious sympathies of the Tatar elite. When analyzing both narratives, we will try to answer the question to what extent can we trust the reliability of their information about the impact of Uzbek's religious affiliation on the expected change in his relations with the Russian principalities?

\section{Religious Situation within the Golden Horde}

Uzbek Khan's ascension to the Golden Horde power in early 1313 and his almost three-decade long reign was of undeniable importance in rooting Islam in the ulus of Jochi ${ }^{1}$. Firstly, Islam became noticeably stronger in Golden Horde urban centers that developed in the Volga and other regions of the ulus of Jochi at the very time of Uzbek Khan's reign. Islamic contemporary sources and the results of archaeological surveys clearly indicate both the expansion of Islamic areas in Golden Horde cities and the widespread construction of Muslim religious buildings. The establishment of urban Islam in the ulus of Jochi clearly showed the influence of the Muslim religion as an obvious consequence of the religious sym-

\footnotetext{
${ }^{1}$ This statement is the most widely used in studies published in Russian, which obviously prevail among the works analyzing the reign of Uzbek Khan. See, for example: [14, p. 131; 13, p. $608 ; 39$, p. 589,$591 ; 11$, p. $99-100 ; 15$, p. 59,126$]$. But cfr. with: [49, passim; 48, p. 7].
} 
pathies of Uzbek Khan and his closest entourage [see, for example: 48, p. 25; 10, p. $48-49 ; 12$, p. $110 ; 50$, p. $82 ; 16$, p. $60-64 ; 47$, p. $179 ; 39$, p. 593].

On the other hand, Muslim written sources paid much less attention to confessional changes in the steppe despite the fact that the nomads continued to play a leading role in the political life of the Golden Horde and most likely, significantly exceeded the urban population, leading Mamluk writer al-Umari to underline the fact that most of Uzbek's subjects consisted of 'tents' inhabitants living in the steppes" [45, p. 230].

The nomads represented the main military and political force in the Golden Horde and religious sympathies of the Jochid rulers often depended on the confessional orientation of those political factions of nomads who provided these rulers with crucial military support at the time of their ascension to power [55, p. 121]. In cases where struggle for succession led to a clash between warring nomadic factions with opposing religious orientations, the victory of one of these factions and, consequently, the enthronement of its representative, implied the physical destruction of the new khan's competitors and even the forced religious conversion of their subordinates. In view of these considerations, the Muslim chroniclers presented Uzbek's ascension as a result of a battle between nomads with opposing religious sympathies and assumed the full conversion to Islam of the opponents of the new ruler following the establishment of his power. On the other hand, the Latin sources compiled within the Golden Horde reflect opposing views on the consequences of Uzbek Khan's ascension and allow us to essentially diversify the notion of this Golden Horde ruler's religious policy.

By the time of Tokhta Khan's death in August 1312, a large and influential newly-converted faction of Muslim nomads had formed in the Golden Horde. According to a statement of a number of Egyptian sources, this faction provided direct support to Uzbek during the struggle for power that raged in the second half of $1312^{2}$. More important, however, was a much more violent conflict that took place within the Golden Horde after Uzbek's ascension at the beginning of 1313. In particular, the earliest report of the Persian chronicler Qashani points on a clash between the new ruler and the adherents of traditional nomadic beliefs. According to Qashani, Uzbek demanded the Tatar amirs abandon the Mongol Yasa in favor of Sharia ${ }^{3}$. After receiving such an ultimatum from their new ruler, the Golden Horde amirs conspired to kill Uzbek, but their plot was exposed in time and Uzbek ordered the execution of more than one hundred representatives of the Tatar elite [54, p. 107-109] ${ }^{4}$.

Apparently, khan Uzbek introduced a policy to forcibly Islamize the nomads immediately after his enthronement and as a consequence he faced fierce resistance

${ }^{2}$ Ibn Duqmaq clearly indicates the support received by Uzbek from a Muslim KutlugTimur who was formerly a senior amir during Tokhta Khan's reign: [45, p. 323; see also: p. $384-385,515-516]$.

${ }^{3}$ It should be noted that according to Qashani, Uzbek's conflict with the Tatar amirs took place before his ascension to power. However, it is more logical to assume that Uzbek was able to demand the Tatar emirs convert to Islam only after he had become a khan [18, p. 112]. In any case, Mamluk sources confirm this assumption. So, Ibn Duqmaq specifies that influential Jochid princes Tunguz and Taz revolted after Uzbek's ascension [45, p. 323].

${ }^{4}$ In the early $15^{\text {th }}$ century, Hafiz-i Abru reproduced almost unchanged Qashani's report [46, p. 141]. See also similar information of Mamluk authors regarding the religious conflict within the Golden Horde: [45, p. 174, 197, 206, 277, 323, 384-385, 515-516]. 
of his subjects. Having suppressed the Tatar amirs' revolt and executed his main opponents, Uzbek did not fail to notice the Mamluk sultan. In 1314, the khan of the Golden Horde dispatched a solemn embassy to Egypt with the obvious intention of restoring the previously friendly and allied relations with the Mamluk Sultanate that had been interrupted seven years earlier by the previous khan Tokhta [53, p. 170]. According to the Mamluk chronicler an-Nuwayri, in March or April of the same year, Uzbek's ambassadors arrived in Cairo with a message of congratulations addressed to the Egyptian sultan "with the spread of Islam from China to the most distant lands of the west" and with clarification that "there had been one remaining party in his realm which adhered to a religion other than Islam, but the king had offered them the choice between conversion to Islam, or war ... they refused conversion and fought, and he attacked them and annihilated them, slaying or capturing them" [45, p. 163]. Thus, the Golden Horde ambassadors not only informed the Sultan about the suppression of all political opposition in the ulus of Jochi, but also about the conversion of all of its nomads to Islam.

However, an-Nuwayri's statement on the total Islamization of the ulus of Jochi was based on the words of Uzbek's ambassadors and did not necessarily correspond to reality. It is quite possible that the statement regarding the destruction of all "infidels" in the domain of Uzbek contained deliberate exaggeration allowed by diplomatic etiquette and serving as the most appropriate means for resuming political relations between Egypt and the Golden Horde [49, p. 71-72; 55, p. 121; 48, p. 7; 54, p. 94-95].

Here we must turn to the Franciscan sources written within the Golden Horde and during the reign of Uzbek Khan. These sources contain valuable information regarding the religious situation in urban centers and steppe regions of the ulus of Jochi. But more importantly, they completely refute the Uzbek ambassadors' assertion. In March 1314 (in parallel with the arrival of Uzbek's embassy in Cairo), the Golden Horde khan granted yarlik to the Franciscans of Caffa confirming a number of privileges and exemption from military duties and taxes. It is significant to note that Uzbek Khan allowed the Franciscans complete freedom of movement throughout the Golden Horde territory for the purpose of preaching "Christian law" and he also gave them the right to complain to the khan's chancellery when confronted with any obstacles in the course of fulfilling their missionary activity [51, p. $65 ; 9$, p. 35-36, 39]. It is obvious that this authorization of unobstructed preaching of "infidel" priests in the Golden Horde contradicted the alleged intention of Uzbek to force the Jochid ulus' population to adopt the Islamic religion $[69$, p. 111; 70, p. 399. Cfr.: 13, p. 608].

Catholic missionaries in the Golden Horde immediately took advantage of the khan's permission and, in particular, the Hungarian Franciscan Johanca wrote in his letter addressed in 1320 to the General Minister of his Order, that in 1314 he traveled to the territory of modern Bashkortostan to preach the Gospel. When describing the conditions of Catholic missionary development throughout the territory of the ulus of Jochi, Johanca exalted those of his fellows who had spared no efforts to preach the Gospel in the steppe "following the Tartar camps". At the same time, Friar Johanca did not mention any obstacles from the Golden Horde administration, which he faced in person "in Bascardia" only after allowing himself to publicly question the legitimacy of the Muslim faith [51, p. 66-68; 1, p. 90-93]. 
Also, the letter by the Franciscans of Caffa in 1323 reported the Franciscans' significant missionary progress through daily preaching of the Gospel in the steppe and Umbrian Minorite Giovanni Elemosina's "Chronicon" of 1336 described how Christian rituals were integrated into nomadic everyday life [66, p. 107; 65, p. 361; 8, p. $96 ; 60$, p. 125].

Contemporary Franciscan sources pointed to a sizeable expansion of Christianity in the ulus of Jochi; however, they also noted with regret the fact that a significant part of the local nomads remained adherents of traditional steppe beliefs [66, p. 111; 65 , p. $365 ; 8$, p. 100]. More importantly, these written sources pointed to the preservation of the Chinggisids' traditional principles of religious tolerance during the reign of Uzbek Khan ${ }^{5}$. The same Franciscan authors pointed to a complete confessional autonomy - which was extended to all the religious communities of the Jochid ulus - and also emphasized the strict compliance with autonomous rights by the Golden Horde administration until they did not violate the secular interests of the local legislation [66, p. 107,$111 ; 65$, p. $361 ; 8$, p. 96; 51, p. 66; 1, p. 90; 60, p. 125].

Summing up the various information of sources, we can draw the following conclusions about the religious policy of Uzbek Khan. It is most likely that Uzbek Khan used the example of the bloody suppression of the opposition in order to present to the Egyptian Sultan his domain as a full-fledged Islamic State with predominant Muslim population [53, p. 175]. Apart from the Crimean cities, the Muslim population really prevailed in the Golden Horde urban centers. Nevertheless, Latin contemporary sources show that a significant portion of the Jochid ulus' nomads (who continued to represent a major political and military power of the Golden Horde) remained adherents of traditional beliefs of the steppe, showing their sympathies for the Christian or Muslim religions according to personal preferences.

Apparently, Uzbek Khan actually tried to conduct a program of forced Islamization of his domain, but impressed by the fierce resistance caused by this program among the nomads, he was forced to return to the traditional policy of religious tolerance already in the second year of his reign.

\section{Uzbek's Enthronement in Russian Chronicles and Yarlik of Metropolitan Peter}

So, the new ruler came to power in the Golden Horde in 1313 as a result of a fierce internal struggle. In addition, the new Jochid khan was a Muslim. Therefore, Russian subjects of Uzbek Khan had to be interested in the events connected with the change of power. However, in comparison with the abundant information of Oriental sources, Russian chronicles contain very little information about the vicissitudes of Uzbek's enthronement.

We can find several explanations for this phenomenon. First of all, the chronicle svods (collections) that we have currently in our possession were compiled in $100-200$ years after these events. Probably, Russian compilers of the $15^{\text {th }}-16^{\text {th }}$ centuries did not consider events of 1312-1313 so important to give them any attention. In addition, generally speaking the authors of Russian chronicles were little

\footnotetext{
${ }^{5}$ See the corresponding letters of gratitude addressed by the Roman Pontiffs to Uzbek during the whole of his reign, who perceived the tolerance of a Jochid ruler as a special Uzbek's predisposition towards Christianity: [61, p. 44, 178-181; 62, p. 227-228, 252, 260].
} 
interested in events in the Horde and focused on the description of only those events that were directly related to the Russian principalities and their rulers.

The latter observation leads us to an even more curious conclusion: that the Russian chroniclers paid so little attention to Muslim sympathies of Uzbek, suggests that change of religious orientation of the new khan of the Golden Horde did not affect his Orthodox subjects [54, p. 93-94]. So, Sofiyskaya I chronicle (in older and younger editions) does not mention any events in the Horde under the year 6821 (1313) [30, col. 371; 29, p. 205]. The Tverite Rogozhsky chronicler only limited himself with a mention of Tokhta Khan's death and Uzbek's enthronement [34, p. 36]. A more verbose Trinity chronicle explains the reasons for a trip to the Horde of the Tverite prince Michael Yaroslavovich and Metropolitan Peter in the same 1313: the Moscow chronicler of the early $15^{\text {th }}$ century reports that Michael and Peter had to go to the Horde after the death of Tokhta Khan and subsequent enthronement of a Muslim Uzbek [25, p. 354]. Simeonovskaya chronicle reproduces this report, together with an indication of the rapid Metropolitan's return to Rus' $\left[35\right.$, p. 88]. The Moscow chronicle svod of the late $15^{\text {th }}$ century does the same thing, but its author omits references to Uzbek's conversion to Islam [37, p. 160; see also: 36, p. $97 ; 31$, p. 186]. The author of Nikon collection considers it appropriate, as usual, to give a more detailed explanation: in connection with Uzbek's enthronement all the princes and prelates had to gather in the Horde and each of them received the personal yarlik authorizing their rule. Nikon chronicle also omits references to Uzbek's conversion, but it reports that Metropolitan Peter soon returned from Uzbek "with great honor" [32, p. 178; see also: 4, p. 47-48, nota 35].

Apparently, the initial report on the trip of the Tverite Prince and the Metropolitan to the Horde appeared in the Tverite svod of 1327, which has not been preserved to the present day. After that, this report underwent significant changes in the Moscow svod and formed the basis of Trinity chronicle's report compiled in 1408. The Trinity chronicle's version was borrowed by a number of those Moscow svods that we have at our disposal. Finally, this report underwent a thorough edition of Nikon collection in 1520s. In this case, the author of Nikon chronicle used additional materials from the Metropolitan archives in Moscow. These documents were used in parallel during the preparation of other important collection - "Extensive edition" of the "Collection of Yarliks Granted to the Russian Metropolitans" [44, p. 51-52].

In turn, the "Collection of Yarliks Granted to the Russian Metropolitans" represent the particular interest as an example of how Russian Orthodox church used the granted charters of the Golden Horde khans to advocate its own material benefits. The very first edition of the "Collection" was composed in the middle of the $15^{\text {th }}$ century as proof of the immutability of ecclesiastical rights to the property, which the Jochid rulers granted to the Russian metropolitans in the past centuries. In addition, the content of khans' yarliks gave reason to the full legal independence of the Orthodox clergy from the local secular authorities. However, the Metropolitan Office in Moscow considered it appropriate to publish "Extensive edition" of the "Collection" in 1540s to more convincingly justify its privileges. In particular, "Extensive edition" was supplemented by Uzbek Khan's yarlik granted to Metropolitan Peter in 1313. To become more convincing the authors of "Extensive edition" anticipated the text of yarlik with an explanatory "Foreword" describing the Metropolitan's trip to the Horde [see the texts of yarlik as well as of "Foreword" in: 
42 , p. $8-10 ; 5$, p. 112-118]. This "Foreword" is similar to the entry in Nikon chronicle, but, as we shall see, it contains additional information [44, p. 49; 24, p. 142 $143 ; 23$, p. $182 ; 22$, p. $90 ; 6$, p. $7 ; 20$, p. 464-465].

It was proved as soon as the early $20^{\text {th }}$ century that Uzbek's yarlik added to "Extensive edition" had been forged [43, passim; 20, p. 464; 23, p. 182]: in addition to an unusually extensive volume of the text, the content of this act is not quite consistent with the standard form of khans' yarliks. And first of all, the addition of "Extensive edition" contains two contradictory and apparently incorrect datings of the year 1213 (6721) according to the Old Russian calendar and of the year 1315 (of hare) according to the Mongol animal cycle [5, p. 112, 118; 24, p. 144]. For their part, several aforementioned chronicles imply that Uzbek Khan granted yarlik to the Metropolitan in 1313, in connection with Peter's visit to the Horde.

Despite the fact that Uzbek's yarlik is preserved only in the form of a counterfeit, there is no doubt that these falsification based on the really existed yarlik. Most likely, the original content of this yarlik corresponded to yarlik of khan Möngke-Timur granted to Metropolitan Kirill on 1 August, 1267 [see the text of Möngke-Timur's yarlik in: 42, p. 5-6; 5, p. 124-126; 20, p. 467-468]. Accordingly, yarlik of 1313 contained a number of prescriptions for the Golden Horde officials, which confirmed exemption of the Orthodox church from paying a number of taxes and from fulfillment of duties. At the same time, the yarlik's text had to be addressed to the Grand Prince of Vladimir with the approval of the full legal autonomy of the Metropolitan and his subordinates. Nevertheless, svodchiki of the Metropolitan Office of the $16^{\text {th }}$ century felt that these privileges were not described in sufficient detail and significantly expanded the yarlik's text [24, p. 144-146; 22, p. 89-90; 20, p. 464, 476].

The content of "Foreword" to both the forged yarlik of Uzbek and the whole "Extensive edition" is very interesting as well. Obviously, in his description of the Metropolitan trip to the Horde the author of "Foreword" based on the same source as did the svodchik of Nikon chronicle. However, this "Foreword" contain additional information about the reasons that prompted the Metropolitan to quickly travel to the Horde. Among these reasons, "Foreword" mentions the desire of Russian prelate to get ahead of "foreign ${ }^{6}$ ambassadors, and Matthew, a Bishop of the Roman Pope" in getting khan's privileges [5, p. 111]. We can only guess who were these "foreign ambassadors" mentioned by the author of "Foreword". On the other hand, we can put forward a relatively plausible hypothesis in regard to the Catholic prelate of the "Roman Pope". The following assumption is made possible thanks to the relatively numerous Latin sources on synchronous activity of Catholic missionaries in Crimea.

First of all, it should be noted here that the anonymous author of "Foreword" apparently confused the name of Catholic Bishop: a Dominican Matteo Manni of Cortona became the second Latin Bishop of Caffa only 12 years after the Metropolitan's trip [64, p. 113; 63, p. 19; 61, p. 57]. The real leader of Catholic missionaries in the Crimea in 1313 was Bishop Jerome of Catalonia. Jerome arrived in the Crimea as early as 1311 and he was actively involved in negotiations with Uzbek Khan on the return of the Franciscans to Caffa, from where they had been expelled

\footnotetext{
${ }^{6}$ Actually, here stays the adjective "nemeckie", literally "mutes" - generic name of foreigners who did not speak Russian.
} 
by the previous khan Tokhta in 1308. It is quite possible that Jerome was sent to the Crimea as the official representative of the Holy See exactly for the negotiations with the Golden Horde khan [68, p. 156-158; 70, p. 476; 59, p. 302]. He apparently succeeded in negotiating and obtained from Uzbek the granting of yarlik, which has been mentioned above [51, p. 65; 9, p. 36]. Nevertheless, Uzbek granted his yarlik to the Franciscans in 1314 only, that is, about a year after the Metropolitan Peter's trip.

Thus, Metropolitan Peter indeed was able to get yarlik a year earlier than the Franciscans. Although we still do not understand the reasons for his concerns about the possibility that Catholics could have gain privileges before the Orthodox church. Be that as it may, the contents of both Uzbek's yarliks have certain similarities. Both the forged yarlik in Russian translation and authentic yarlik translated by the Franciscans into Latin include the provision of full legal autonomy of the Latin and the Orthodox churches $[5$, p. $113 ; 51$, p. $65 ; 9$, p. 36]. The presence of both yarliks shows that a Muslim Uzbek was inclined to take into account the religious sympathies of his other-religious subjects: the Golden Horde khan conferred upon the Orthodox and Latin churches considerable privileges and demanded in return only to pray God for himself, "for his wives, children and his lineage" [5, p. $114 ; 51$, p. $65 ; 9$, p. 36]. Uzbek obviously attached great importance to this requirement and according to the author of the "Life of Metropolitan Peter", the Orthodox prelate strictly fulfilled his obligations [57, p. 107-108].

In return of obtained privileges, Peter consistently served the political interests of Uzbek and the Moscow princes - the main allies of the Golden Horde khan in North-Eastern Rus' [56, p. 72-73, 90]. Also, his successor Feognost who replaced Peter on the metropolitan chair in 1326, adhered to the same political line. So, three years later Feognost expelled from Pskov the Tverite prince Alexander Mikhailovich who had previously resisted a representative of the Horde power [28, p. $262-263 ; 27$, p. $90 ; 37$, p. $169 ; 7$, p. $102-103 ; 67$, p. $22 ; 56$, p. $117-118 ; 21$, p. 55]. In 1334, his mediation contributed to reconciliation between the Novgorodians and Grand Prince Ivan Kalita: thanks to Theognost's participation in negotiations the Novgorodians abandoned their transient alliance with Lithuania, and Great Novgorod came back into the sphere of the Golden Horde influence [56, p. 147-148; 2, p. 504]. It is obvious that Uzbek's religious tolerance contributed to the achievement of actual political goals of the Jochid khan.

\section{The Tale of Michael of Tver}

Returning to references to Uzbek's conversion to Islam in Russian sources, we should pay special attention here to the narrative of the execution in the Horde of the Tverite prince Michael Yaroslavovich. As it will be shown below, this Tale enjoyed increased popularity among Russian authors and has preserved both in nonchronicle sources, as well as in a number of chronicle svods. But first of all, we should briefly describe the events that formed the basis of the Tale.

The Tale's events are connected with the moment of a sharp aggravation of the struggle between Moscow and Tver principalities. At the same time, the Horde's ruler provided direct support to the prince of Moscow Yuri Danilovich. In early 1317, the Tverite prince Michael achieved another submission of the Great Novgorod. At once, Michael suddenly learned that Uzbek Khan decided to take away his 
title of Grand Duke and to transmit it to the prince of Moscow. Thus, the Moscow prince returned from the Horde with Tatar reinforcements headed by Kavgadyj and invaded the principality of Tver. Michael did not dare to resist the invading troops for a long time, but on December 22 the prince of Tver inflicted a decisive defeat on the military forces of Yuri Danilovich. As a result of the battle, Konchak, Yuri's Tatar wife and sister of khan Uzbek, was captured by Michael. Konchak died in captivity under unclear circumstances, which became one of the reasons for the subsequent execution of the Tverite prince.

Michael captured the Tatar military commander Kavgadyj as well, but treated him with respect and let him go to the Horde. After that Kavgadyj launched a vigorous activity in the khan's camp and persuaded Uzbek to call both princes in the Horde for trial. For some time Michael doubted the necessity of travel, but the Tatar envoy Akhmyl gave him clearly to understand that it was a matter of the safety of his principality. Upon arriving in the khan's camp in September 1318, Michael learned that Kavgadyj and Yuri of Moscow had already set up against him the main part of the khan's approximates. Russian sources describe further a two-month's trial in the khan's camp in extremely gloomy colors emphasizing its unfair nature. The trial ended with the execution of Michael on 22 November, attended by Kavgadyj and Yuri Danilovich [17, p. 125-163; 34, cols. 36-40; 33, cols. 409-421; 25, p. 356; 30, cols. $375-396 ; 29$, p. $207-215 ; 37$, p. $161-166 ; 36$, p. $98-100 ; 32$, p. $180-186 ; 41$, p. 209, 286-287; 7, p. 98-101; 4, p. 49-52; 56, p. 81-87; 2, p. 468].

The content of the Tale has clear hagiographic character, but nevertheless it is based on real events. Its author was an eyewitness of these events. Probably, he was a confessor of Michael - Alexander - who went to the Horde along with the prince of Tver. After the execution of the prince, Alexander returned to Tver and soon compiled there his narrative, which undergone later numerous editions. The so-called "Extensive edition" represents the most complete and early version of the Tale, whose critical edition was published by Vladimir Kuchkin. Kuchkin considered this edition as the most reliable, though he pointed out that he used copies of the $16^{\text {th }}-17^{\text {th }}$ centuries. In turn, John Fennell reasonably pointed to the possibility that preserved copies of "Extensive edition" may contain later interpolations similar to those versions that were included in the chronicle svods [17, p. 116; 58, p. 94].

For its part, the Tale developed in two directions in the chronicle svods. The stressed anti-Tatar narrative is impressed in the Tverite chronicles, although this version is presented in a much abbreviated form. A more complete and neutral version is presented in the pro-Moscow chronicles, where it first occurs in Sofiyskaya First chronicle. In the end, the two branches of the Tale's evolution meet again in the vast Nikon svod, whose author gives a number of detailed (and possibly fictitious) explanations to the described events [38, p. 111-112; 58, p. 94-95].

Following the "Extensive edition", it is the Moscow cycle of the Tale who provides an indication of the changes that occurred in connection with Uzbek Khan's ascension to the Golden Horde power. After describing how Michael Yaroslavovich had received the title of Grand Prince from the previous khan Tokhta and mentioning an unsuccessful attempt of the prince of Moscow to challenge this decision, "Extensive edition" reports on the ascension of the tsar "called by the name of Ozbyak" who entered the "Saracen faith, detestable to God". In connection with this, the Tale reports that subsequently Uzbek ceased to spare "Christian people", and he quotes 
from the book of Daniel about the Babylonian captivity of the people of Israel. In this quote Uzbek is compared with the cruel Babylonian king Nebuchadnezzar and then the author compares the khan with Emperor Titus who captured Jerusalem, and with Phokas the Cappadocian who took possession of Constantinople [17, p. 132-133; see also: 40 , p. $113 ; 38$, p. 117-118]. The Tverite chronicles omit this entire fragment, but the Moscow authors reproduce it necessarily. The only exception is the author of Nikon svod distinguished by respectful attitude toward Uzbek [30, cols. 377-378; 29, p. 208; 37, p. 161; 32, p. 182].

It is clear that the author of the Tale wished to emphasize all those negative consequences that were caused, in his view, by Uzbek's ascension to power. His further narrative is equally clear in showing that Uzbek abandoned the traditional support of the Tver principality in favor of the prince of Moscow. According to the author of the Tale, this change in the political line eventually led to the execution of Michael - in his view, of the only legitimate Grand Prince. However, the Tale points to the religious preferences of the Golden Horde khan only in this passage. Subsequently, the author never mentions Uzbek's religious affiliation. Therefore, it remains unclear to us, how Uzbek's conversion to Islam influenced the development of subsequent events.

Later, the author of the Tale evinces a certain reverence for Uzbek. In particular, "Extensive edition" reports Michael's words that the prince of Moscow Yuri received the title of Grand Prince from "God and the tsar" [17, p. 134]. It is possible that in this case "Extensive edition" sought to emphasize Michael's attempt to peacefully resolve the dispute with the prince of Moscow. However, the Moscow editors of the Tale considered it appropriate to omit the mention of God in this phrase [30, col. 378; see also: 29 , p. 208; 37, p. $162 ; 36$, p. 99; 32, p. 182]. Probably, they considered unacceptable the possibility of interpretation that Russian princes received investiture yarliks not only by the will of the khan, but also from God.

Throughout the Tale, Uzbek is incited against Michael. However, the biased attitude of Uzbek is imposed as a charge not on khan himself, but on Kavgadyj. Kavgadyj is the main negative character of the narrative, showing furthermore an extreme ingratitude towards the generous act of Michael. The Tverite prince not only saved the Kavgadyj's life after his capture, but he also gave him all kinds of honors and dismissed the Tatar commander unharmed to the Horde. For his part, upon returning to the Horde, Kavgadyj forced the prince of Moscow to compile a number of false testimonies against Michael and he accused the prince of Tver in the concealment of tribute that Michael had to pay to Uzbek [17, p. 138; see also: 30 , col. $381 ; 29$, p. 209; 37, p. $162 ; 36$, p. 99; 32, p. 182; 4, p. 50-51; 2, p. 470].

In turn, the Tverite chronicles call Uzbek the "lawless tsar" when describing the trial of Michael [34, col. 39; 33, col. 411]. Obviously, in this way the authors of the Tverites svods sought to emphasize the unfair nature of the trial in the Horde. However, we should note that the author of "Extensive edition" did not allow himself to use such a harsh epithet. The same expression is absent in the Moscow chronicles as well. In any case, in all editions of the Tale Uzbek entrusts the trial to the Tatar "princes" and has no direct influence on its course. The same Kavgadyj is the main culprit for rendering an unjust sentence, who simultaneously serves as a judge, prosecutor and false witness in the case $[17$, p. 141-142; 34, cols. 38-39; 33, col. 411; 30, cols. 383-384; 29, p. 210; 37, p. 163; 36, p. 99]. Curiously, the Nikon svodchik presents Uzbek as seeking a just sentence. In his interpretation, Uzbek 
rejects Kavgayj's decision after the first judicial session and assigns a second one, since "the tsar's court should be righteous" [32, p. 183].

Description of the events in Uzbek's camp includes the details, which can be interesting to consider the functioning of the Golden Horde court or the route of the khan's horde's movement from the Don steppes to the foothills of the Northern Caucasus. But it was hardly the author's intention to acquaint the readers with the activities of the khan's camp. The author of the Tale was an eyewitness to the events, but he did not deign to attention the fact that during his movement to the south Uzbek was preparing to invade the territory of the neighboring Ilkhanate [46, p. $86-89 ; 3$, p. $146-147 ; 52$, p. 408].

A detailed description of the trial served the purpose to show that Michael was sentenced to death for crimes he did not commit. All editions of the Tale agree that charges of tribute's concealment had no reason. However, the svodchiks' opinions are divided with regard to Michael's charges of murdering Konchak - the khan's sister and the wife of Yuri Danilovich. The Tverite chronicles do not consider it appropriate to express their judgments in this regard, but the author of Sofiyskaya First chronicle rejects accusations of murder [30, col. 375. Cfr.: 34, col. 38; 33, col. 410]. Nevertheless, other Moscow chronicles clearly accuse Michael of poisoning Konchak. Probably, they are doing it to mitigate the guilt of the prince of Moscow, who took part in the trial and subsequent execution of Michael [25, p. 356; see also: 35 , p. $88 ; 37$, p. $161 ; 36$, p. 98]. Only the author of the Nikon chronicle expresses some doubts about Michael's crime [32, p. 181].

Regardless of the degree of confidence in Michael's innocence of the authors of various editions of the Tale, all the versions, without an exception, point to the central merit of the Tverite prince, which became the main base for his future canonization. Michael Yaroslavovich faced with a difficult choice before his departure to the Horde: whether to admit the inevitable Tatar attack on his principality or to sacrifice his life for the salvation of his Orthodox subjects? The Tverite prince decided to sacrifice himself and further description of the Tatar unfair trial was to emphasize the degree of Michael's heroism. The author of the Tale collated Michael with the classic martyrs Boris and Gleb and he compared the Tverite prince's self-denial with firmness in the faith of the Chernigov prince Michael, who had been executed in the Golden Horde camp three-quarters of a century before these events [7, p. 99, 101-102; 4, p. 58, nota 111; 2, p. 469]. However, unlike his Chernigov namesake, Michael Yaroslavovich was not compelled to apostasy. Mention of Uzbek's conversion to Islam was to emphasize the unfair nature of subsequent trial of a single figure of Michael. However, the author of the Tale was not trying to look for obvious signs of those tragic consequences for the Orthodox population of the North-Eastern Rus', which could be associated with the change of religion of the new Golden Horde khan. Obviously, he would not failed to do so, if he would had grounds for this.

\section{The Tver Uprising in 1327 or "Scholkanovschina"}

Seven years after the execution of Michael of Tver, his son Dmitry was able to avenge his father by killing the Moscow prince Yuri Danilovich in the Horde. Apparently, Dmitry saw Yuri the main culprit in the death of his father. In turn, Uzbek 
was forced to punish Dmitry Mikhailovich for arbitrariness, although khan postponed the sentencing for nearly a year: Dmitry Mikhailovich was executed in the Horde September 15, 1326. After the execution, Uzbek faced a difficult choice: whether to give yarlik for the Grand Princedom to the Moscow prince Ivan Kalita or to grant it to the house of Tver? In the end, khan decided to grant yarlik to Alexander Mikhailovich of Tver, brother of the executed Dmitry. Uzbek's decision showed that despite previous executions in the Horde, the Jochid khan continued to trust and give preference to the Tverite princes [7, p. 102; 4, p. 60; 56, p. 101]. Uzbek had to change his sympathy only after the tragic events that followed.

Alexander Mikhailovich probably returned from the Horde to Tver in the spring of 1327. After that, a large Tatar detachment headed by Cholkhan (Shevkan or Schelkan in Russian chronicles) arrived there. Apparently, Cholkhan was entrusted to collect an extraordinary tax from Tverite inhabitants in compensation for yarlik recently received in the Horde by the prince of Tver. Thus, Cholkhan performed a legitimate and ordinary order of the Golden Horde khan on Russian territories. However, while performing this order, the Tatar envoy allowed himself to resort to excessive and imprudent harassment of the local population, which caused the outbreak of spontaneous popular uprising on August 15, 1327. The Tverite prince was compelled to join the uprising, in which all the Tatars in Tver, including Cholkhan, were killed. Six months after that, a punitive Tatar expedition came to Rus', which consisted of five tumens and additional units of the Moscow prince Ivan Kalita. In the course of counter-insurgency operations the main towns of the Tver principality was looted. In turn, Alexander Mikhailovich fled to Pskov, and he was able to return to Tver only 10 years later, after having received Uzbek's consent on that $[19$, p. $98 ; 34$, cols. $42-44 ; 33$, cols. 415-416; 25, p. 358-359; 28 , p. $260-261 ; 26$, p. $16 ; 27$, p. $90-91 ; 29$, p. $217-218 ; 37$, p. $168 ; 32$, p. $194 ; 7$, p. $102,105-106 ; 4$, p. $60-61 ; 67$, p. $151-152 ; 56$, p. 101, 120].

Such is the brief history of events led to a dramatic weakening of the Tver principality's influence in Rus'. What we are most interested in here, is the evolution of Russian chronicles' representation of Cholkhan's intentions and actions, which led to the only major Tatar campaign in the North-Eastern Rus' for the whole period of Uzbek's reign.

The older edition of Novgorod First chronicle - the closest Russian source to the events - does not provide any comment on the matter and is limited to mention that the Tverite prince killed many Tatars with the Bulgar merchants in Tver and other cities of the principality $[19$, p. 98]. Probably, also a primary Tverite report had an equally impartial nature, which undergone subsequently significant changes. In the earliest edition of Rogozhsky chronicler and Tver collection this report is complemented by a later author's reflections about how Devil inspired evil intentions towards Christians in the hearts of "godless" Tatars. In particular, Devil inspires the Tatars to kill Alexander Mikhailovich and all the other princes to "obtain power over them". Here Cholkhan acts as the main initiator of diabolical plan and he obtains Uzbek's permission for its implementation. In turn, Alexander Mikhailovich tries in every way to avoid an open clash with the Tatars and the beginning of revolt is entirely attributed to the citizens of Tver [34, cols. 42-43; see also: 33 , col. 415; 4, p. 60-61; 67, p. 151-152; 2, p. 476].

Obviously, the Tverite version of the report had an immediate impact on subsequent editions. However, these editions complemented the narrative with some 
significant details based on a common and unpreserved protograph. New version appears in Novgorod Fourth chronicle, from where it enters the Pskovite chronicles. The same version is reproduced in a similar form in Sofiyskaya First chronicle, from where it is borrowed by the author of the Moscow chronicle svod of $1479[7$, p. $104 ; 4$, p. $60-61 ; 56$, p. $105-106]$.

New version of the report on the Tver uprising does not conceal its desire to justify Ivan Kalita's participation in both its suppression as well as the following unsuccessful attempt to arrest the Tverite prince in Pskov: in both cases, the prince of Moscow did not dare to disobey Uzbek's commands. The author of new version does not condemn the fact of uprising, but he attributes its beginning to the initiative of the Tverite prince. Before the beginning of uprising, Alexander Mikhailovich calls upon the Tverites to avenge the death of his father Michael and brother Dmitry. To justify thoughtless actions of Alexander, Cholkhan here is plotting much more serious crimes against Christians: the Tatar envoy intends to occupy the throne of Tver and impose his governors in all the towns of the principality. And, what is more important for the present topic, Cholkhan plans to forcibly convert all Christians to Islam [28, p. 260-261; see also: 26 , p. 16 ; 27, p. 90-91; 29, p. $217-$ $218 ; 37$, p. $168 ; 4$, p. 60-61; 56, p. 105-106]. For its part, Nikon chronicle does not complement the narrative with essential details, except for questionable indications that Cholkhan was a cousin of Uzbek. Probably, the author of Nikon svod sought to reinforce in such way the soundness of khan's anger, to which description he pays considerable attention [32, p. 194; see also: 7, p. 104].

Summing up this brief analysis of the evolution of the report on the Tver uprising, we should admit that its later editions contain a number of details, which, apparently, did not correspond to the historical reality. Probably, Uzbek commissioned Cholkhan to collect an extraordinary tax in the Tver principality. But the Golden Horde khan did hardly allow his envoy to create a separate Tatar appanage in Rus'. In any case, the Tatars headed by Fedorchuk did not try to do it later, when they suppressed the uprising, even though they had at their disposal sufficient military forces to do it.

In this context, a reference to attempts at forced conversion of the Orthodox population to Islam is interesting as the only indication of the consequences of the gradual Islamization of Tatar elite. However this mention, most likely, was an invention of the later editors of the report as well. Apparently, Russian svodchiki of the $15^{\text {th }}$ century attributed to Cholkhan the desire to subjugate Russian towns to the power of Tatar governors under the influence of later events, in particular, of Edigu's invasion of Rus' in the early $15^{\text {th }}$ century [2, p. 491]. Cholkhan was compared with Edigu - his coreligionist - and the presence of Muslim merchants in Tver during the uprising reinforced the conviction of the insidious (though fictional) intentions of Tatar envoy, including the forcible imposition of Islam.

On this we should conclude our consideration of the influence of Uzbek's religious sympathies on the North-Eastern Rus', since Russian medieval sources do not provide additional material for reflection on this subject. In conclusion, it will be appropriate to repeat that scarcity of material on the subject indirectly indicates that the change of religious affiliation of the supreme ruler of Rus' did not have a significant impact on the character of his reign. 
Roman Hautala. Russian Chronicles on the Religious Policy of Uzbek Khan...

\section{REFERENCES}

1. Anninskiy S.A. Izvestiya vengerskikh missionerov XIII-XIV vv. o tatarakh i vostochnoy Evrope [Reports of Hungarian Missionaries of the $13^{\text {th }}-14^{\text {th }}$ centuries about the Tatars and Eastern Europe]. Istoricheskiy arkhiv [Historical Archive]. Moscow, Leningrad, Akademiya nauk SSSR Publ., 1940, no. 3, pp. 71-112. (In Russian)

2. Cherepnin L.V. Obrazovanie russkogo tsentralizovannogo gosudarstva v XIV-XV vekakh [Formation of the Russian Centralized State in the $14^{\text {th }}-15^{\text {th }}$ centuries]. Moscow, Izdatel'stvo sotsial'no-ekonomicheskoy literatury, 1960. 899 p. (In Russian)

3. Cherkas B. Zakhidni volodinnya Ulusu Dzhuchi: politichna istoriya, teritorial'noadministrativniy ustriy, ekonomika, mista. (XIII-XIV st.) [Western Possessions of the Ulus of Jochi: Political History, Territorial-Administrative Structure, Economics, Towns $\left(13^{\text {th }}\right.$ $14^{\text {th }}$ centuries)]. Smoliy V.A. (ed.). Kyiv, Institut istoriï Ukraïni, 2014. 387 p. (In Ukrainian)

4. Gorskiy A.A. Moskva i Orda [Moscow and the Horde]. Moscow, Nauka Publ., 2000. 213 p. (In Russian)

5. Grigor'ev V.V. O dostovernosti yarlykov, dannykh khanami Zolotoy Ordy russkomu dukhovenstvu. Istoriko-filologicheskoe issledovanie [On the Reliability of Yarliks Granted by the Golden Horde Khans to the Russian Clergy. Historical and Philological Research]. Moscow, Universitetskaya tipografiya, 1842, 132 p. (In Russian)

6. Grigor'ev A.P. Sbornik khanskikh yarlykov russkim mitropolitam. Istochnikovedcheskiy analiz zolotoordynskikh dokumentov [Collection of Khans' Yarliks Granted to the Russian Metropolitans. A Source Study Analysis of the Golden Horde Documents]. St. Petersburg, Sankt-Peterburg State Universitet Publ., 2004. 276 p. (In Russian)

7. Halperin Ch. Tatarskoe igo: obraz mongolov v srednevekovoy Rossii [The Tatar Yoke: The Image of the Mongols in Medieval Russia]. Kopylova M.E. (tr.). Voronezh, Voronezh State Universitet Publ., 2012. 230 p. (In Russian)

8. Hautala R. Dva pis'ma frantsiskantsev iz Kryma 1323 goda: latinskiy tekst, russkiy perevod i kommentarii [Two Franciscan Letters from the Crimea (1323): Latin Text, Russian Translation, and Commentary]. Zolotoordynskaya tsivilizatsiya=Golden Horde Civilization. Kazan, Sh.Marjani Institute of History of Tatarstan Academy of Sciences, 2014, no. 7, pp. 87-110. (In Russian)

9. Hautala R. Yarlyk Uzbeka frantsiskantsam Zolotoy Ordy 1314 goda: latinskiy tekst, russkiy perevod i kommentarii [Yarlik of Uzbek Khan Granted to the Franciscans of the Golden Horde in 1314: The Latin Text, Russian Translation, and Commentary]. Zolotoordynskoe obozrenie=Golden Horde Review. Kazan, Sh.Marjani Institute of History of Tatarstan Academy of Sciences, 2014, no. 3, pp. 31-48. (In Russian)

10. Izmaylov I.L. Islam $\mathrm{v}$ Zolotoy Orde [Islam in the Golden Horde.]. Islam $i$ musul'manskaya kul'tura v Srednem Povolzh'e: istoriya i sovremennost'. Ocherki [Islam and Muslim Culture in the Middle Volga Region: History and Present. Essays]. Kazan, Master Layn, 2002, pp. 38-61. (In Russian)

11. Izmaylov I.L. Islam i yazychestvo v Uluse Dzhuchi: problemy i diskussii [Islam and Paganism in the Ulus of Jochi: Problems and Discussion]. Vostok - Zapad: Dialog kul'tur Evrazii. Problemy srednevekovoy istorii $i$ arkheologii [East-West: Dialogue of Cultures of Eurasia. Questions of Medieval History and Archaeology]. Kazan, Sh.Marjani Institute of History of Tatarstan Academy of Sciences 2004, no. 4, pp. 99-107. (In Russian)

12. Izmaylov I.L. Prinyatie islama v Uluse Dzhuchi: prichiny i etapy islamizatsii [The Adoption of Islam in the Ulus of Jochi: Causes and Stages of Islamization]. Islam $i$ vlast' $v$ Zolotoy Orde. Sbornik statey [Islam and the Power in the Golden Horde. Collected Papers]. Mirgaleev I.M., Sayfetdinova E.G. (eds.). Kazan, Sh.Marjani Institute of History of Tatarstan Academy of Sciences, 2012, pp. 98-117. (In Russian)

13. Izmaylov I.L., Usmanov M. Islam v Uluse Dzhuchi [Islam in the Ulus of Jochi]. Istoriya tatar s drevneyshikh vremen $v$ semi tomakh. Tom III: Ulus Dzhuchi (Zolotaya Orda). XIII - seredina XV v. [The History of the Tatars from the Earliest Times in Seven 
Volumes. Vol. III: The Ulus of Jochi (The Golden Horde). $12^{\text {th }}-$ middle of the $15^{\text {th }}$ centuries]. Usmanov M., Khakimov R. (eds.). Kazan, Sh.Marjani Institute of History of Tatarstan Academy of Sciences, 2009, pp. 599-617. (In Russian)

14. Islaev F.G. K voprosu ob islamizatsii Zolotoy Ordy [On the Islamization of the Golden Horde]. Zolotoordynskoe nasledie. Vypusk 2: Materialy vtoroy Mezhdunarodnoy nauchnoy konferentsii «Politicheskaya $i$ sotsial'no-ekonomicheskaya istoriya Zolotoy Ordy», posvyashchennoy pamyati M.A.Usmanova. Kazan', 29-30 marta 2011 g. [Golden Horde Legacy. Iss. 2: Proceedings of the Second International Conference "The Political and Socio-Economic History of the Golden Horde", in memory of M.A. Usmanov. Kazan, $29^{\text {th }}-30^{\text {th }}$ March, 2011]. Mirgaleev I.M. (ed.). Kazan, Sh.Marjani Institute of History of Tatarstan Academy of Sciences, 2011, pp. 129-134. (In Russian)

15. Kobishchanov Yu.M. Imperiya Dzhuchidov [The Empire of the Jochids]. Ocherki istorii rasprostraneniya islamskoy tsivilizatsii. $V$ dvukh tomakh. Vol. 2: Epokha velikikh musul'manskikh imperiy i Kairskogo Abbasidskogo Khalifata (seredina XIII - seredina XVI v.) [Essays on the History of the Spread of Islamic Civilization. In Two Volumes. Vol. II: The Era of the Great Muslim Empires and the Abbasid Caliphate in Cairo (middle of the $13^{\text {th }}$ - middle of the $16^{\text {th }}$ centuries)]. Moscow, "Rossiyskaya politicheskaya entsiklopediya" (ROSSPEN), 2002, pp. 13-130. (In Russian)

16. Kramarovskiy M.G. Chelovek srednevekovoy ulitsy. Zolotaya Orda. Vizantiya. Italiya [The Man of Medieval Streets. The Golden Horde. Byzantium. Italy]. St. Petersburg, Evraziya Publ., 2011. 544 p. (In Russian)

17. Kuchkin V.A. Prostrannaya redaktsiya Povesti o Mikhaile Tverskom [Extensive Edition of the Tale of Michael of Tver]. Srednevekovaya Rus' [Medieval Rus']. Moscow, Editorial USSR, 1999, no. 2, pp. 116-163. (In Russian)

18. Lapshina I. Voprosy votsareniya i smerti Uzbek-khana [Questions of Acsension to Power and Death of Uzbek Khan]. Zolotoordynskaya tsivilizatsiya=Golden Horde Civilization. Kazan, Sh.Marjani Institute of History of Tatarstan Academy of Sciences, 2013, no. 6, pp. 112-120. (In Russian)

19. Novgorodskaya pervaya letopis' starshego i mladshego izvodov [Older and Younger Editions of the Novgorod First Chronicle]. Nasonov A.N. (ed.). Moscow, Leningrad, Akademiya nauk SSSR Publ., 1950. 561 p. (In Russian)

20. Pamyatniki russkogo prava. Vypusk 3: Pamyatniki prava perioda obrazovaniya russkogo tsentralizovannogo gosudarstva $X I V-X V$ vv. [Monuments of the Russian Law. Issue 3: Judicial Monuments from the Period of the Russian Centralized State's Establishment in the $14^{\text {th }}-15^{\text {th }}$ centuries]. Cherepnin V.L. (ed.). Moscow, Gosudarstvennoe izdatel'stvo yuridicheskoy literatury, 1955. 527 p. (In Russian)

21. Pashuto V.T. Obrazovanie litovskogo gosudarstva [Formation of the Lithuanian State]. Moscow, Akademiya nauk SSSR Publ., 1959. 531 p. (In Russian)

22. Pochekaev R.Yu. Zolotoordynskie yarlyki russkoy tserkvi kak primer pravootnosheniy svetskoy i dukhovnoy vlasti na gosudarstvennom i nadgosudarstvennom urovne [The Golden Horde Yarliks to the Russian Church as an Example of the Legal Relations between Secular and Spiritual Power at the State and Supra-State Levels]. Politikopravovye osnovy sotsial'nogo partnerstva gosudarstva i traditsionnykh konfessiy. Materialy nauchno-prakticheskoy konferentsii. Sankt-Peterburg, 3 iyunya 2004 g. [Political and Legal Basis for the Social Partnership between the State and Traditional Confessions. Proceedings of the research and practical conference. St. Petersburg, $3^{\text {rd }}$ June, 2004]. St. Petersburg, 2005, pp. 88-92. (In Russian)

23. Pochekaev R.Yu. Pravo Zolotoy Ordy [The Law of the Golden Horde]. Kazan, Sh.Marjani Institute of History of Tatarstan Academy of Sciences, 2009. 259 p. (In Russian)

24. Pochekaev R.Yu. Poddel'nye akty zolotoordynskikh praviteley i ikh real'nye prototipy [Counterfeit Acts of the Golden Horde Rulers and Their Real Prototypes]. Aktual'nye problemy istorii i kul'tury tatarskogo naroda. Materialy $k$ uchebnym kursam. V 
chest' yubileya akademika AN RT M.A. Usmanova [Actual Problems of the History and Culture of the Tatar People. Materials for the training course. In honor of the anniversary of academician of the Academy of Sciences of the Republic of Tatarstan, M.A. Usmanov]. Kazan, Ministerstvo obrazovaniya i nauki Respubliki Tatarstan, 2010, pp. 142-154. (In Russian)

25. Priselkov M.D. Troitskaya letopis'. Rekonstruktsiya teksta [Trinity Chronicle. Reconstruction of the Text]. Moscow, Leningrad, Akademiya nauk SSSR Publ., 1950. 512 p. (In Russian)

26. Pskovskie letopisi. Is. I [Pskov Chronicles. Iss. I]. Nasonov A.N. (ed.). Moscow, Leningrad, Akademiya nauk SSSR Publ., 1941. 146 p. (In Russian)

27. Pskovskie letopisi. Is. II [Pskov Chronicles. Iss. II]. Nasonov A.N. (ed.). Moscow, Akademiya nauk SSSR Publ., 1955. 363 p. (In Russian)

28. Polnoe sobranie russkikh letopisey. Tom IV. Part 1: Novgorodskaya Chetvertaya letopis'. Is. 1 [Complete Collection of Russian Chronicles. Vol. IV. P. 1: Novgorod Fourth Chronicle. Iss. 1]. Petrograd, Tipografiya Ya. Bashamokv i Ko, 1915. 320 p. (In Russian)

29. Polnoe sobranie russkikh letopisey. Tom V: Pskovskie i Sofiyskie letopisi [Complete Collection of Russian Chronicles. Vol. V: Pskov and Sofian Chronicles]. St. Petersburg, v Tipografii Eduarda Pratsa, 1851. 275 p. (In Russian)

30. Polnoe sobranie russkikh letopisey. Tom VI. Is. 1: Sofiyskaya Pervaya letopis' starshego izvoda [Complete Collection of Russian Chronicles. Vol. VI. Iss. 1: Older Edition of Sofiyskaya First Chronicle]. Moscow, Yazyki russkoy literatury, 2000. 581 p. (In Russian)

31. Polnoe sobranie russkikh letopisey. Tom VII: Letopis' po Voskresenskomu spisku [Complete Collection of Russian Chronicles. Vol. VII: Chronicle According to Resurrection Copy]. St. Petersburg, v Tipografii Eduarda Pratsa, 1856. 345 p. (In Russian)

32. Polnoe sobranie russkikh letopisey. Tom X: Letopisnyy sbornik, imenuemyy Patriarshey ili Nikonovskoy letopis'yu [Complete Collection of Russian Chronicles. Vol. X: Chronicle Collection Called Patriarchal or Nikon Chronicle]. Saint Petersburg, v Tipografii ministerstva vnutrennikh del, 1885. 244 p. (In Russian)

33. Polnoe sobranie russkikh letopisey. Tom XV: Letopisnyy sbornik, imenuemyy Tverskoy letopis'yu [Complete Collection of Russian Chronicles. Vol. XV: Chronicle Collection Called Tver Chronicle]. St. Petersburg, v Tipografii Leonida Demisa, 1863. 540 p. (In Russian)

34. Polnoe sobranie russkikh letopisey. Tom XV. Is. 1: Rogozhskiy letopisets [Complete Collection of Russian Chronicles. Vol. XV. Iss. 1: Rogozhsky Chronicler]. Petrograd, 1922. 216 p. (In Russian)

35. Polnoe sobranie russkikh letopisey. Tom XVIII: Simeonovskaya letopis' [Complete Collection of Russian Chronicles. Vol. XVIII: Simeonovskaya Chronicle]. St. Petersburg, Tipografiya M.A. Aleksandrova, 1913. 316 p. (In Russian)

36. Polnoe sobranie russkikh letopisey. Tom XXIII: Ermolinskaya letopis' [Complete Collection of Russian Chronicles. Vol. XXIII: Ermolinskaya Chronicle]. St. Petersburg, Tipografiya M.A. Aleksandrova, 1910. 239 p. (In Russian)

37. Polnoe sobranie russkikh letopisey. Tom XXV: Moskovskiy letopisnyy svod kontsa $X V$ veka [Complete Collection of Russian Chronicles. Vol. XXV: Moscow Chronicle Svod of the end of the $15^{\text {th }}$ century]. Moscow, Leningrad, Akademiya nauk SSSR Publ., 1949. 462 p. (In Russian)

38. Rudakov V.N. Mongolo-tatary glazami drevnerusskikh knizhnikov serediny XIII$X V v v$. [The Mongol-Tatars in the Eyes of the Ancient Russian Scribes of the middle of the $13^{\text {th }}-15^{\text {th }}$ centuries]. Moscow, Kvadriga Publ., 2009. 248 p. (In Russian)

39. Schamiloglu U. Vysokaya islamskaya kul'tura Zolotoy Ordy [The Islamic High Culture of the Golden Horde]. Istoriya tatar s drevneyshikh vremen v semi tomakh. Tom III: Ulus Dzhuchi (Zolotaya Orda). XIII - seredina XV v. [The History of the Tatars from the Earliest Times in Seven Volumes. Vol. III: The Ulus of Jochi (The Golden Horde). $12^{\text {th }}$ 
middle of the $15^{\text {th }}$ centuries]. Usmanov M., Khakimov R. (red.). Kazan, Sh.Marjani Institute of History of Tatarstan Academy of Sciences, 2009, pp. 589-598. (In Russian)

40. Seleznev Yu.V. Opisanie svoego (russkogo) i chuzhego (ordynskogo) prostranstva v "Zhitie Mikhaila Tverskogo" [Description of Own (Russian) and Others' (Horde) Space in the "Life of Michael of Tver"]. Vestnik Voronezhskogo gosudarstvennogo universiteta. Seriya: Istoriya. Politologiya. Sotsiologiya [Bulletin of Voronezh State University. Series: History. Political Science. Sociology]. Voronezh, Voronezh State Universitet Publ., 2007, no. 2, pp. 112-114. (In Russian)

41. Seleznev Yu.V. Russkie knyaz'ya v sostave pravyashchey elity Dzhuchieva Ulusa v $X I I I-X V$ vekakh [Russian Princes as a Part of the Ruling Elite of the Ulus of Jochi in the $13^{\text {th }}-15^{\text {th }}$ centuries]. Voronezh, Tsentral'no-Chernozemnoe knizhnoe izdatel'stvo, 2013. 472 p. (in Russian)

42. Sobranie gosudarstvennykh gramot $i$ dogovorov, khranyashchikhsya $v$ Gosudarstvennoy Kollegii inostrannykh del. Chast' vtoraya, sluzhashchaya dopolnenie $k$ pervoy [Collection of State Charters and Treaties Preserved in the State Collegium of Foreign Affairs. Part Two Serving as Addition to the First One]. Moscow, v Tipografii Selivanovskogo, 1819. 610 p. (In Russian)

43. Sokolov P.P. Podlozhnyy yarlyk khana Uzbeka mitropolitu Petru [Forged Yarlik of Uzbek Khan Granted to Metropolitan Peter]. Rossiyskiy istoricheskiy zhurnal [Russian Historical Journal]. Petrograd, 1918, no. 5, pp. 70-85. (In Russian)

44. Sochnev Yu.V. K otsenke dostovernosti svedeniy predisloviya $\mathrm{k}$ yarlyku khana Uzbeka o konfessional'noy politike ordynskikh vlastiteley [Regarding the Evaluation of Reliability of the Information on the Golden Horde Rulers' Confessional Policy Containing in the Foreword to Uzbek Khan's Yarlik]. Zolotoordynskaya tsivilizatsiya. Sbornik statey [Golden Horde Civilization. Collected Papers]. Kazan, Sh.Marjani Institute of History of Tatarstan Academy of Sciences, 2013, no. 6, p. 49-60. (In Russian)

45. Tiesenhausen V.G. Sbornik materialov, otnosyashchikhsya $k$ istorii Zolotoy Ordy. Tom 1: Izvlecheniya iz sochineniy arabskikh [Collection of Materials Related to the Golden Horde History. Vol. 1: Excerpts from Arab Writings]. St. Petersburg, Tipografiya Imperatorskoy Akademii Nauk, 1884. 579 p. (In Russian)

46. Tiesenhausen V.G. Sbornik materialov, otnosyashchikhsya k istorii Zolotoy Ordy. Tom 2: Izvlecheniya iz persidskikh sochineniy [Collection of Materials Related to the Golden Horde History. Vol. 2: Excerpts from Persian Writings]. Romaskevich A.A., Volin S.L. (eds.). Moscow, Leningrad, Akademiya nauk SSSR Publ., 1941. 310 p. (In Russian)

47. Usmanov M.A. Etapy islamizatsii Dzhuchieva ulusa i musul'manskoe dukhovenstvo v tatarskikh khanstvakh XIII-XVI vekov [Stages of Islamization of the Ulus of Jochi and Muslim Clergy in the Tatar Khanates of the $13^{\text {th }}-16^{\text {th }}$ centuries]. Dukhovenstvo $i$ politicheskaya zhizn' na Blizhnem i Srednem Vostoke v period feodalizma [Clergy and Political Life in the Near and Middle East in the Period of Feudalism]. Kim G.F., Girs G.F., Davidovich E.A. (eds.). Moscow, Nauka Publ., 1985, pp. 177-185. (In Russian)

48. Vasil'ev D.V. Islam v Zolotoy Orde. Istoriko-arkheologicheskoe issledovanie [Islam in the Golden Horde. Historical and Archaeological Research]. Astrakhan, Izdatel'skiy dom "Astrakhanskiy Kreml"', 2007. 191 p. (In Russian)

49. Yurchenko A.G. Khan Uzbek: Mezhdu imperiey i islamom (struktury povsednevnosti). Kniga-konspekt [Uzbek Khan: Between Empire and Islam (daily life structures). Compendium Book]. St. Petersburg, Evraziya Publ., 2012. 400 p. (In Russian)

50. Zilivinskaya E.D. Kul'tovye postroyki vremeni Uzbeka v Zolotoy Orde [Religious Buildings in the Golden Horde of the Time of Uzbek Khan]. Zolotoordynskaya tsivilizatsiya. Sbornik statey [Golden Horde Civilization. Collected Papers]. Kazan, Sh.Marjani Institute of History of Tatarstan Academy of Sciences, 2013, no. 6, pp. 82-97. (In Russian) 
51. Bihl M., Moule A.C. Tria nova documenta de missionibus Fr. Min. Tartariae Aquilonaris annorum 1314-1322. Archivum Franciscanum Historicum. Quaracchi, Firenze, Collegio S. Bonaventura, 1924, no. 17, pp. 55-71. (In Latin)

52. Boyle J.A. The Dynastic and Political History of the Il-Khāns. The Cambridge History of Iran. Vol. 5: The Saljuq and Mongol Periods. Idem (ed.). Cambridge, UK, Cambridge University Press, 1968, pp. 303-421.

53. Ciocîltan V. The Mongols and the Black Sea Trade in the Thirteenth and Fourteenth Centuries. Willcocks S. (tr.). Leiden, Boston, Brill Academic Publishers, 2012. $321 \mathrm{p}$.

54. DeWeese D.A. Islamization and Native Religion in the Golden Horde. Baba Tūkles and Conversion to Islam in Historical and Epic Tradition. University Park, Pennsylvania State University Press, 1994. 656 p.

55. DeWeese D.A. Islamization in the Mongol Empire. The Cambridge History of Inner Asia. The Chinggisid Age. Di Cosmo N., Allen F.J., Golden P.B. (eds.). Cambridge, New York, Cambridge University Press, 2009, pp. 120-134.

56. Fennell J.L.I. The Emergence of Moscow: 1304-1359. London, Secker \& Warburg, 1968. $352 \mathrm{p}$.

57. Fennell J.L.I. The Ideological Role of the Russian Church in the first half of the fourteenth century. Publications of the Modern Humanities Research Association, 2: A Garland of Essays Offered to Professor Elizabeth Mary Hill. Hill E.M., Auty R., Lewitter L.R., Vlasto A.P. (eds.). Cambridge, Modern Humanities Research Association, 1970, pp. $105-111$.

58. Fennell J.L.I. V.A. Kučkin: Povesti o Michaile Tverskom. Istoriko-tekstologičeskoe issledovanie. Russia Mediaevalis. Muenchen, Wilhelm Fink Verlag, 1977, III, pp. 93-98.

59. Golubovich G. Biblioteca bio-bibliografica della Terra santa e dell'Oriente francescano. Vol. I: Il secolo decimoterzo (1215-1300). Quaracchi, Firenze, Collegio di S. Bonaventura, 1906. 479 p. (In Italian, Latin)

60. Golubovich G. Biblioteca bio-bibliografica della Terra santa e dell'Oriente francescano. Vol. II: Addenda al sec. XIII e fonti pel sec. XIV. Quaracchi, Firenze, Collegio di S. Bonaventura, 1913. 641 p. (In Italian, Latin)

61. Golubovich G. Biblioteca bio-bibliografica della Terra santa e dell'Oriente francescano. Vol. III: Dal 1300 al 1322. Quaracchi, Firenze, Collegio di S. Bonaventura, 1919. 496 p. (In Italian, Latin)

62. Golubovich G. Biblioteca bio-bibliografica della Terra santa e dell'Oriente francescano. Vol. IV: Dal 1333 al 1345. Quaracchi, Firenze. Collegio di S. Bonaventura, 1923. 503 p. (In Italian, Latin)

63. Loenertz R.J. Les Missions dominicaines en Orient au quatorzième siècle et la Société des frères pérégrinants. Archivum fratrum praedicatorum. Romae, Institutum Historicum Fratrum Praedicatorum Romae ad S. Sabinae, 1932, no. 2, pp. 1-83. (In French)

64. Loenertz R.J. La Société des Frères Pérégrinants. Vol. I: Étude sur l'Orient dominicain. Roma, Istituto Storico Domenicano, 1937. 209 p. (In French)

65. Moule A.C. Fourteenth Century Missionary Letters. The East \& the West: A Quarterly Review for the Study of Missionary Problems. Westminster, Society for the Propagation of the Gospel in Foreign Parts, 1921, no. 19, pp. 357-366.

66. Moule A.C. Textus duarum epistolarum Fr. Minorum Tartarie Aquilonaris an. 1323. Archivum Franciscanum Historicum. Quaracchi, Firenze, Collegio S. Bonaventura, 1923, no. 16/1-2, pp. 104-112. (In Latin)

67. Ostrowski D. Muscovy and the Mongols: Cross-Cultural Influences on the Steppe Frontier, 1304-1589. Cambridge, Cambridge University Press, 1998. 329 p.

68. Richard J. La Papauté et les missions d'Orient au Moyen Age (XIII $-X V^{e}$ siècles). Rome, École Française de Rome, 1998. 331 p. (In French) 
69. Sinor D. Some Latin Sources on the Khanate of Uzbek. Essays on Uzbek History, Culture, and Language. Nazarov B., Sinor D., DeWeese D.A. (eds.). Bloomington, Indiana University, Research Institute for Inner Asian Studies, 1993, pp. 110-119.

70. Soranzo G. Il Papato, l'Europa cristiana e i Tartari. Milano, "Vita e pensiero", Pubblicazioni dell’Università Cattolica del Sacro Cuore, 1930. 624 p. (In Italian)

About the author: Roman Hautala - Ph.D. (History), Senior Research Fellow, Usmanov Center for Research on the Golden Horde and Tatar Khanates, Sh.Marjani Institute of History of Tatarstan Academy of Sciences (7, Baturin Str., Kazan 420111, Russian Federation); Docent, Historical branch at the Faculty of Humanities, University of Oulu, ORCID: http://orcid.org/0000-0003-3898-0107, ResearcherID: H-9114-2016 (1, Pentti Kaiteran Str., Historia, PL 1000, 90570, University of Oulu, Oulu, Finland). E-mail: romanhautala@gmail.com

\title{
РУССКИЕ ЛЕТОПИСИ О РЕЛИГИОЗНОЙ ПОЛИТИКЕ ХАНА УЗБЕКА (1313-1341) И ЕГО ОТНОШЕНИЯХ С КНЯЖЕСТВАМИ СЕВЕРО-ВОСТОЧНОЙ РУСИ
}

\author{
Роман Хаутала ${ }^{1,2}$ \\ ${ }^{I}$ Институт истории им. Ш. Марджани АН РТ \\ Казань, Российская Федераџия \\ ${ }^{2}$ Университет Оулу \\ Оулу, Финляндия \\ romanhautala@gmail.com
}

\begin{abstract}
Цель исследования: автор настоящей статьи рассматривает общую реакцию русских средневековых авторов на приход к власти хана Узбека - золотоордынского правителя, который был мусульманином и предпринял значительные усилия для распространения ислама в Золотой Орде. При анализе русских источников автор стремится ответить на вопрос, в какой степени мы можем довериться достоверности их сведений о влиянии конфессиональной принадлежности Узбека на предполагаемое изменение в его отношениях с русскими княжествами?

Материаль исследования: русские источники имеют первостепенное значение для изучения истории Золотой Орды. В особенности русские летописи содержат богатый фактологический материал. Изобилие этого материала объясняется тем фактом, что средневековая Русь была подчинена Золотой Орде, хотя ее многочисленные и разрозненные князья пользовались значительной автономией внутри джучидской

С другой стороны, достоверность информации русских летописей не следует переоценивать по нескольким причинам. Сохранившиеся летописные своды были нередко составлены через несколько столетий после описываемых событий. Поэтому их информация подверглась значительным идеологическим изменениям. Кроме того,
\end{abstract} империи. 
Roman Hautala. Russian Chronicles on the Religious Policy of Uzbek Khan... 755

авторы русских летописей фокусировались на описании только тех явлений, которые были непосредственно связаны с русскими княжествами или их правителями.

Новизна данного исследования заключается в сравнении сведений русских летописей с информацией малоизученных письменных источников. В частности, латинские источники, составленные внутри улуса Джучи в относительно большом количестве именно в период времени, который рассматривается в данной статье, в некоторой степени возмещают полное отсутствие собственно джучидских письменных источников. Содержание латинских источников в данном случае позволяет пересмотреть устоявшееся мнение о тотальной исламизации улуса Джучи в правление Узбека.

Результаты исследования: значимость настоящей статьи заключается в использовании разнородных письменных источников. Сравнение содержания русских летописей с информацией католических миссионеров, проповедовавших Евангелие внутри Золотой Орды, позволяет продемонстрировать, что мусульманский хан Узбек продолжал придерживаться принципов традиционной религиозной толерантности Чингизидов в течение всего своего правления.

Ключевые слова: Золотая Орда, Северо-Восточная Русь, правление хана Узбека, исламизация татар, русские летописи, латинские источники

Для цитирования: Hautala R. Russian Chronicles on the Religious Policy of Uzbek Khan (1313-1341) and His Relations with the Principalities of the North-Eastern Rus' // Золотоордынское обозрение. 2017. Т. 5, № 4. C. 736-755. DOI: 10.22378/23136197.2017-5-4.736-755

Сведения об авторе: Роман Хаутала - Ph.D. (история), старший научный сотрудник Центра исследований Золотой Орды и татарских ханств им. М.А.Усманова Института истории им. Ш. Марджани АН РТ (420111, ул. Батурина, 7, Казань, Российская Федерация); доцент исторического отделения гуманитарного факультета университета Оулу, ORCID: http://orcid.org/0000-0003-3898-0107, ResearcherID: H-9114-2016 (90570, ул. Пентти Кайтера, 1, История, почтовый ящик 1000, университет Оулу, Оулу, Финляндия). E-mail: romanhautala@gmail.com 